\section{Helicobacter pylori and anemia: a community-based cross-sectional study among adults in Southern Brazil}

\author{
Helicobacter pylori e anemia: um estudo \\ transversal de base populacional entre \\ adultos no Sul do Brasil
}

Iná S. Santos 1

Gicele Costa Minten 1

Neiva C. J. Valle 1

Giovana Costa Tuerlinckx 1

José Boccio 2

Domingo Andrés Barrado 2

Alessandra Banaszeski da Silva 1

Guilherme Augusto Reissig Pereira 1

\title{
Background
}

\footnotetext{
${ }_{1}$ Programa de Pós-graduação em Epidemiologia

Universidade Federal de Pelotas, Pelotas, Brasil.

2 Facultad de Farmacia y Bioquímica, Universidad de Buenos Aires, Buenos Aires, Argentina.

Correspondence

G. C. Minten

Programa de Pós-graduação em Epidemiologia,

Universidade Federal de Pelotas.

Rua Marechal Deodoro 1160 , 3o piso, C.P. 464, Pelotas, RS 96020-220, Brasil.

giceleminten.epi@gmail.com
}

\section{Abstract}

To investigate the association between Helicobacter pylori and anemia, a community-based cross-sectional study was conducted among 1845 year old users of the 31 primary health care units in Pelotas, Southern Brazil. Interviews us ing a structured questionnaire were carried out in waiting rooms during two work shifts. Anemia (hemoglobin $<11 \mathrm{~g} /$ dL among pregnant women, $<12 \mathrm{~g} /$ dL among women and < 13g/dL among men) was diagnosed from capillary blood (HemoCue) and $\mathrm{H}$. pylori by means of a ${ }^{13} \mathrm{C}-U B T$. Information on socio-demographic, behavioral and biological characteristics was collected. Logistic and linear regression analyses were carried out, taking into account aggregated primary health care units. A total of 1,117 respondents fulfilled the inclusion criteria (losses/refusals: $8.1 \%$ ). Prevalence of anemia was 20.6\% (18.2-23.2\%) and of $\mathrm{H}$. pylori, 70.7\% (68.0-73.6\%). After allowing for age, sex and skin color the odds ratio for anemia among those who were diagnosed $\mathrm{H}$. pylori positive was 0.94 (0.70-1.27). After allowing for sex, skin color, family monthly income, age, and smoking, the reduction in hemoglobin among $\mathrm{H}$. pylori positive respondents was $0.07 \mathrm{~g} / \mathrm{dL}$ (-0.24-0.11; $p=0.4)$. There is no association between $\mathrm{H}$. pylori and anemia among adults attending primary health care units in Southern Brazil.

Helicobacter pylori; Anemia; Adult
Identification of the effect of Helicobacter pylori on the digestive system has given rise to studies of the risk factor of this infection for extra-gastric diseases. It has been proposed that $H$. pylori may be responsible for iron deficiency, among other risks. The factors that lend biological plausibility to this association include the deficiency in iron absorption by $H$. pylori-colonized gastric cells, competition for iron between gastric cells and $H$. pylori, and bleeding through peptic ulcers and other gastric lesions associated with H. pylori 1,2 .

Anemia is a major public health problem in developing countries. The main causes of anemia include: dietary iron deficiency; infectious diseases such as malaria, hookworm infections and schistosomiasis; deficiencies of other key micronutrients including folate, vitamin B12 and vitamin A; and inherited conditions that affect red blood cells, such as thalassaemia. Nonetheless, about half of all cases of anemia can be attributed to iron deficiency ${ }^{3}$. Accordingly, if an association between $H$. pylori and anemia is demonstrated, eradication of this bacterium could become an important public health strategy for controlling anemia in developing countries.

The present study was planned to investigate the association between $H$. pylori colonization and anemia among adult users of the primary health care network in the city of Pelotas, in Southern Brazil. 


\section{Methods}

This was a community-based cross-sectional study carried out in all 31 primary health care facilities within the Unified National Health System (SUS) in the urban area of the municipality of Pelotas between August 2006 and February 2007. The study included adults aged 18 to 45 who were present in waiting rooms for consultations for any reason, and also the accompanying persons, provided that they too were users of the city's primary health care facilities.

Two pairs of interviewers received prior training to apply standardized pre-coded questionnaires, take anthropometric measurements and carry out two tests on the interviewees: HemoCue (HemoCue Corp., Ängelholm, Sweden) and 13CUrea Breath Test (13C-UBT; Fischer Analysen Instrumente $\mathrm{GmbH}$, Leipzig, Germany). The procedures were implemented during two work shifts of each primary health care unit (two mornings on two consecutive days).

Those who fulfilled the eligibility criteria and agreed to participate were required to complete a structured questionnaire on demographic (age, sex and skin color), socio-economic (family monthly income, marital status and schooling) and behavioral characteristics (smoking and consumption of alcoholic drinks, greens/raw vegetables, beans, eggs/yolks, meat and viscera). Current or previous medical diagnoses of anemia and hemorrhoids, and report of blood in feces were also investigated. In the case of female respondents, additional questions were asked regarding reproductive and menstrual characteristics (number of previous pregnancies, age at menarche, duration of menstrual flow, and current contraceptive method).

An aluminum anthropometer of $1 \mathrm{~cm}$ accuracy and a UNICEF (United Nations Children Fund) dry balance of $100 \mathrm{~g}$ accuracy and $150 \mathrm{~kg}$ capacity were used for anthropometric measurements. The body mass index (BMI) was calculated as the person's weight (in $\mathrm{kg}$ ) divided by the square of their height (in meters). Quality control to check reliability of some of the questions was done by means of applying a reduced questionnaire by telephone to approximately $10 \%$ of the interviewees, selected randomly. The kappa statistic of agreement with a previous diagnosis of anemia was 0.80 .

Anemia was assessed by measuring the hemoglobin in capillary blood by means of a portable hemoglobin meter (HemoCue): $<11 \mathrm{~g} / \mathrm{dL}$ in pregnant women; $<12 \mathrm{~g} / \mathrm{dL}$ in non-pregnant women; and $<13 \mathrm{~g} / \mathrm{dL}$ in men ${ }^{3}$.
Because fasting for at least six hours was required, the ${ }^{13} \mathrm{C}-\mathrm{UBT}$ was performed in the morning of the day following the interview. Individuals with Del 13 PDB variation between air samples before and after dosing that was greater than 3.5 per mil were defined as $H$. pylori-positive 4 .

For sample size calculation, the following parameters were set: alpha 0.05 , power $80 \%$, ratio of exposed to non-exposed of 3:1, relative risk $\geq 2.0$ and anemia prevalence among non-exposed of $10 \%$. In accordance with these parameters, and adding $15 \%$ for losses and refusals and $30 \%$ for controlling for confounding, a sample size of 909 individuals was needed.

All the analyses took into account the clustering of the data in primary health care facilities. Multivariable analyses included variables associated with anemia and the presence of $H$. pylori with $\mathrm{p}$-values $<0.20$. Crude and adjusted odds ratios (OR) were obtained with their respective $95 \%$ confidence intervals $(95 \% \mathrm{CI})$ by means of logistic regression. Hemoglobin was also analyzed as a continuous variable through linear regression. The analyses were performed using the Stata 9.0 software (Stata Corp., College Station, United States).

The study was approved by the Research Ethics Committee at the School of Medicine of the Federal University of Pelotas and by the Municipal Department of Health and Social Wellbeing of Pelotas. Before enrollment, the participants signed an informed consent form. The results from the tests were forwarded to respective doctors to consider necessary treatment.

\section{Results}

A total of 1,554 adults attended the 31 primary health care units during the two work shifts of the fieldwork. Of these, 432 were ruled out for not meeting the age criterion and five on account of physical and/or mental disabilities. There were 91 losses and refusals, corresponding to an overall no-response rate of $8.1 \%$.

The HemoCue test was administered to 1,007 individuals. Prevalence of anemia was $20.6 \%$ (95\%CI: 18.2-23.2\%). Among the 1,001 participants who underwent the $13 \mathrm{C}-\mathrm{UBT}$, the prevalence of $H$. pylori colonization was $70.7 \%$ (95\%CI 68.0-73.6\%). As shown in Figure 1, 14.7\% of the individuals presented both $H$. pylori infection and anemia.

Table 1 shows the sample distribution and anemia prevalence according to socio-demographic and consumption habit variables. Compared to white participants, the prevalence of anemia amongst black/mixed subjects was about 


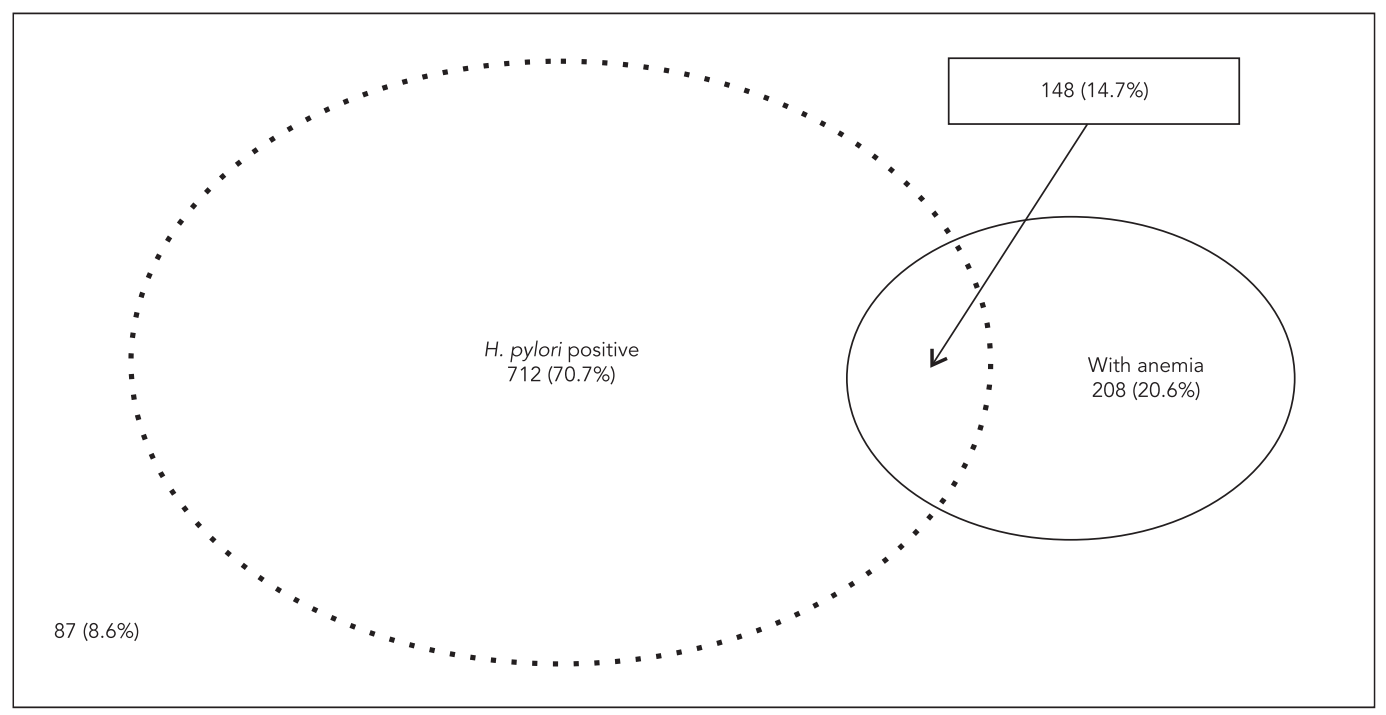

twice as high $(\mathrm{p}<0.001)$. There were no statistically significant differences in anemia prevalence in relation to the other socio-demographic variables. Among all the consumption variables, anemia was only associated with consumption of black beans $(p=0.04)$, with the prevalence being higher among individuals who reported daily consumption.

Table 2 shows the sample distribution and anemia prevalence according to current or past reported morbidity. The prevalence of anemia was associated with a history of a current or previous medical diagnosis of anemia. The HemoCue test was positive for $23.4 \%$ of the individuals who reported present or past anemia versus $16.4 \%$ among those with no history of anemia $(p=0.01)$. The reproductive and menstrual characteristics of the female subjects are also shown in Table 2 . No statistically significant association between any of the reproductive or menstrual variables and the anemia prevalence was observed.

There was no difference in anemia prevalence between the $H$. pylori-positive and negative individuals. In both groups, the anemia prevalence was around $21 \%$ (Table 2).

Table 3 shows the results from crude and adjusted analyses of the association between $H$. pylori and anemia. In comparison with the $H$. pylori-negative individuals, taken as a reference group, the crude OR for the $H$. pylori-positive was 1.02 (95\%CI: 0.75-1.39). Inclusion of age, sex and skin color variables did not change this result (adjusted OR $=0.94$; 95\%CI: 0.70-1.27).

The effect of $H$. pylori colonization on the hemoglobin level was also assessed, taking the latter as a continuous variable. Crude multilevel linear regression showed that $H$. pylori was associated with a statistically non-significant reduction of $0.17 \mathrm{~g} / \mathrm{dL}$ (95\%CI: $-0,38-0,05 ; \mathrm{p}=0.12$ ) in the hemoglobin level. After allowing for sex, skin color, income, age, and smoking, the reduction was even smaller: the hemoglobin level of $H$. pyloripositive individuals was $0.07 \mathrm{~g} / \mathrm{dL}$ (95\%CI: -0,240,$11 ; \mathrm{p}=0,4$ ) lower than that observed among the H. pylori negative.

\section{Discussion}

In this study no association was found between H. pylori colonization and anemia. The observed anemia prevalence $(20.7 \%)$ in the present study was moderate and similar to what has been described in other locations in Brazil 5,6. The prevalence of $H$. pylori colonization was high $(70.7 \%)$ and consistent with the findings from a previous study carried out in the same city ${ }^{7}$. No association was observed between the colonization and the presence of anemia. Before discussing the significance of this finding, the particularities 
Table 1

Anemia prevalence according to socio-demographic and behavioral variables. Pelotas, Southern Brazil, 2007.

\begin{tabular}{|c|c|c|c|}
\hline Variable & n $(1,026)$ & Anemia prevalence (\%) & $\mathrm{p}$ value \\
\hline Age (years) & & & 0.21 \\
\hline $18-24$ & 244 & $61(25.0)$ & \\
\hline $25-29$ & 180 & $36(20.0)$ & \\
\hline $30-34$ & 190 & $40(21.1)$ & \\
\hline $35-39$ & 179 & $26(14.5)$ & \\
\hline $40-45$ & 214 & $45(21.0)$ & \\
\hline Sex & & & 0.12 \\
\hline Male & 161 & $25(15.9)$ & \\
\hline Female & 865 & $183(21.5)$ & \\
\hline Skin color & & & $<0.001$ \\
\hline White & 749 & $124(16.6)$ & \\
\hline Black/Mixed & 258 & $84(32.6)$ & \\
\hline Income (as a multiple of the minimum wage) & & & 0.94 \\
\hline$\leq 1.0$ & 208 & $43(20.7)$ & \\
\hline $1.01-2.0$ & 400 & $81(20.3)$ & \\
\hline $2.01-3.0$ & 195 & $43(22.1)$ & \\
\hline$>3.0$ & 203 & $41(20.2)$ & \\
\hline Education level (number of years) & & & 0.78 \\
\hline $0-4$ & 213 & $42(19.7)$ & \\
\hline $5-8$ & 460 & $102(22.2)$ & \\
\hline$\geq 9$ & 334 & $64(19.2)$ & \\
\hline Alcohol consumption & & & 0.89 \\
\hline No & 829 & $172(20.7)$ & \\
\hline Yes & 178 & $36(20.2)$ & \\
\hline Smoking & & & 0.34 \\
\hline No & 471 & $108(22.9)$ & \\
\hline Former smoker & 209 & $40(19.1)$ & \\
\hline Yes & 327 & $60(18.3)$ & \\
\hline Chicken/beef consumption (days/week) & & & 0.93 \\
\hline$<1$ & 28 & $7(25.0)$ & \\
\hline $1-3$ & 229 & $47(20.5)$ & \\
\hline $4-6$ & 103 & $17(17.5)$ & \\
\hline 7 & 647 & $137(21.2)$ & \\
\hline Chicken/cow liver consumption (days/week) & & & 0.29 \\
\hline$<1$ & 808 & $161(19.9)$ & \\
\hline$\geq 1$ & 199 & $47(23.6)$ & \\
\hline Egg/yolk consumption (days/week) & & & 0.95 \\
\hline 0 & 461 & $95(20.6)$ & \\
\hline $1-3$ & 461 & $95(20.6)$ & \\
\hline$\geq 4$ & 85 & $18(21.2)$ & \\
\hline Black bean consumption (days/week) & & & 0.04 \\
\hline$<3$ & 225 & $36(16.0)$ & \\
\hline $4-6$ & 110 & $19(17.3)$ & \\
\hline 7 & 672 & $153(22.8)$ & \\
\hline Green leaf vegetable consumption (days/week) & & & 0.97 \\
\hline$<1$ & 256 & $58(22.7)$ & \\
\hline $1-3$ & 464 & $88(19.0)$ & \\
\hline $4-6$ & 78 & $16(20.5)$ & \\
\hline 7 & 209 & $46(22.0)$ & \\
\hline
\end{tabular}


Anemia prevalence according to biological variables. Pelotas, Southern Brazil, 2007.

\begin{tabular}{|c|c|c|c|}
\hline Variable & $\mathrm{n}(1,026)$ & Anemia prevalence (\%) & $p$ value \\
\hline History of anemia & & & 0.01 \\
\hline No & 391 & 64 (16.4) & \\
\hline Yes (present/past) & 616 & $144(23.4)$ & \\
\hline History of hemorrhoids & & & 0.64 \\
\hline No & 893 & $187(20.9)$ & \\
\hline Yes & 112 & $21(18.8)$ & \\
\hline History of blood in feces & & & 0.40 \\
\hline No & 872 & $185(21.2)$ & \\
\hline Yes & 135 & $23(17.0)$ & \\
\hline Body mass index & & & 0.46 \\
\hline$\leq 24.9$ & 545 & $119(21.8)$ & \\
\hline $25.0-29.9$ & 284 & $55(19.4)$ & \\
\hline$\geq 30.0$ & 177 & $34(19.2)$ & \\
\hline Age at menarche (years) * & & & 0.41 \\
\hline$\leq 11$ & 214 & $46(21.5)$ & \\
\hline $10-14$ & 539 & $110(20.4)$ & \\
\hline$\geq 15$ & 94 & $25(26.6)$ & \\
\hline Number of previous pregnancies * & & & 0.40 \\
\hline 0 & 91 & $14(15.4)$ & \\
\hline $1-3$ & 596 & $135(22.7)$ & \\
\hline$\geq 4$ & 161 & $34(21.1)$ & \\
\hline Contraceptive method * & & & 0.06 \\
\hline Pill & 413 & $85(20.6)$ & \\
\hline IUD/Tubal ligation/Injectable hormones & 171 & $27(15.8)$ & \\
\hline Others & 233 & $62(26.6)$ & \\
\hline Mean duration of menstrual periods (days) * & & & 0.41 \\
\hline $1-4$ & 519 & $112(21.6)$ & \\
\hline $5-7$ & 308 & $70(22.7)$ & \\
\hline$\geq 8$ & 23 & $1(4.3)$ & \\
\hline Helicobacter pylori (13C-UBT) & & & 0.90 \\
\hline Negative & 292 & $60(20.5)$ & \\
\hline Positive & 709 & $148(20.9)$ & \\
\hline
\end{tabular}

IUD: intra-uterine device.

*Women only ( $\mathrm{n}=865)$.

and the possible limitations of the present study need to be considered.

Firstly, this investigation was developed among the users of primary health care units and therefore the sample was not representative of the population of the city as a whole. The primary health care units serve the poorest $30 \%$ of the population living in the urban zone of the city ${ }^{8}$. However, since the objective of the study was to verify whether there was an association between $H$. pylori colonization and anemia, this non-representativeness does not constitute a true limitation to the study 9 . Furthermore, the fact of belonging to the same socio-economic stratum brings a high homogeneity to the sample regarding socio-economic and behavioral characteristics which may possibly be responsible for the lack of association observed between those variables and the occurrence of anemia.

Secondly, there was a higher prevalence of women in the sample studied. It is well known that women use health services more than men $8,10,11$. As demonstrated in other investigations, in the age group studied the anemia prevalence is greater among women ${ }^{3}$. The present study failed to detect a statistically significant difference in anemia prevalence between men and women. This finding may have been due to the lower pro- 
Effect of Helicobacter pylori colonization over prevalence of anemia. Pelotas, Southern Brazil, 2007.

\begin{tabular}{lccc}
\hline Variable & OR & $95 \% \mathrm{Cl}$ & P value \\
\hline H. pylori colonization & & & 0.90 \\
$\quad$ Crude & 1.02 & $0.75-1.39$ & 0.69 \\
$\quad$ Adjusted * & 0.94 & $0.70-1.27$ & \\
\hline
\end{tabular}

* Adjusted for age, sex and skin color.

portion of men in this sample than in the general population, which may have caused the anemia estimate to be less accurate for this group. On the other hand, regarding $H$. pylori colonization prevalence, a previous study among the general population of the same city showed no difference between men and women 7 .

Thirdly, identification of anemia by means of the hemoglobin level may have impaired the capacity of detection of iron-deficiency anemia. Not all anemic individuals are iron deficient and iron deficiency may occur without anemia. Although hemoglobin concentration can provide information about the severity of iron deficiency, measurements of serum ferritin and transferringreceptor provide the best approach for measuring the iron status of populations. In settings where infectious diseases are common, serum ferritin is not a useful indicator because inflammation leads to a rise in serum ferritin levels as a result of the acute phase response to the disease. In general the transferring-receptor level does not rise in response to inflammation so that, when combined with serum ferritin, it is possible to distinguish between iron deficiency and inflammation. This methodological approach however still requires validation in population surveys 12 and in the absence of international agreement on how to assess the iron status of populations, the prevalence of iron deficiency has often been derived from the prevalence of anemia using measurements of blood hemoglobin, even though not all anemia is caused by iron deficiency.

The three largest population-based prevalence studies conducted worldwide found conflicting results with regard to the association between $H$.pyloriand iron deficiency. Milman etal. 13 conducted a cross-sectional population-based study among adults (30-60 years of age) selected at random from the Civil Registration System in Denmark. A total of 4,581 persons were invited to a health examination, of which $78 \%$ accepted to participate and 3,608 entered the survey. The authors found no association between anti- $H$. pylori antibodies and anemia (low hemoglobin levels). However, the probability of low body iron stores (median serum ferritin) was higher among sero-positive individuals than among the seronegative, after controlling for confounding.

A random sample of 2,080 stored sera available from a previous study conducted among Alaska Natives residing in Alaska were tested for IgG antibody to H. pylori by Parkinson et al. 14 . Overall, an association was observed between H. pylori sero-positivity and low serum ferritin levels after adjusting for age and sex (RR: 1.39; $\mathrm{p}=0.055$ ), whereas in the same subjects, $H$. $p y$ lori detected by ${ }^{13} \mathrm{C}$-UBT or fecal antigen test was not 15 .

In the United States, Cardenas et al. 16 used data from the 1999-2000 National Health and Nutrition Examination Survey (NHANES), with 7,462 individuals aged $\geq 3$ years. Association between sero-positivity for H. pylori and iron deficiency (lower serum ferritin level -13.9\%; 95\%CI: $-19.5 ;-8.0 \%)$, iron deficiency anemia $(\mathrm{OR}=2.6$; 95\%CI: 1.5-4.6), and other types of anemia (OR = 1.3; 95\%CI: 1.0-1.7) were observed after adjusting for confounders.

The number of randomized trials carried out to test the effect of $H$. pylori eradication among individuals with iron deficiency anemia, with or without the use of iron salts, is still small. Most of these trials found an improvement in iron stores and correction of the anemia, but they were generally conducted with small numbers of participants $17,18,19$. The biggest randomized trial found in the literature up to the present date was carried out by Gessner et al. 20 in Alaska in 2006. This involved 219 children aged 7-11 years who presented iron deficiency and in whom no association was found between $H$. pylori eradication and improvement in ferritin levels or anemia. 


\section{Conclusion}

This study has produced no evidence to support the hypothesis that $H$. pylori contributes to anemia among users of the SUS in Southern Brazil. This lack of association after ruling out the role of bias and confounding argues against the inclusion of $H$. pylori among the potential risk factors for iron deficiency anemia in Brazil.

\section{Resumo}

Helicobacter pylori tem sido apontado como causa de anemia. Para investigar essa associação, estudo transversal de base populacional foi realizado entre adultos (18-45 anos de idade), usuários das 31 unidades básicas de saúde (UBS), em Pelotas, Sul do Brasil. Entrevistas com questionários estruturados foram feitas nas salas de espera, em dois turnos de trabalho. Anemia (hemoglobina $<11 \mathrm{~g} / \mathrm{dL}$ entre gestantes, $<12 \mathrm{~g} / \mathrm{dL}$ entre mulheres adultas $e<13 \mathrm{~g} / \mathrm{dL}$ entre homens) foi diagnosticada em sangue capilar (HemoCue). H. pylori foi identificado or ${ }^{13} \mathrm{C}$-Urea Breath Test. Foram coletadas informações sócio-demográficas, comportamentais e biológicas. Análise por regressão logística e linear, levando em conta a agregação por UBS. Dos 1.117 elegíveis, foram perdidos ou recusaram-se participar $8,1 \%$. A prevalência de anemia foi $20,6 \%$ (18,2-23,2\%) $e$ H. pylori, 70,7\% (68,0-73,6\%). Após ajuste para idade, sexo e cor, a odds ratio para anemia entre $\mathrm{H}$. pylori positivos foi 0,94 (0,70-1,27). Na análise ajustada para sexo, cor, renda familiar, idade e tabagismo, o nível de hemoglobina foi $0,07 \mathrm{~g} / \mathrm{dL}$ menor $(-0,24-0,11 ; p=0,4)$ entre H. pylori positivos. Não há associação entre H. pylori e anemia entre adultos usuários de UBS no Sul do Brasil.

Helicobacter pylori; Anemia; Adulto

\section{Contributors}

I. S. Santos conceived the study and participated in its design, coordination, analyses, and interpretation of the results, and drafted the manuscript. G. C. Minten and G. C. Tuerlinckx participated in the design of the study, planned the logistics for the data collection, and coordinated the field work. N. J. C. Valle performed the statistical analyses. J. Boccio and D. A. Barrado carried out the laboratory analyses for $13 \mathrm{C}$-UBT tests. A. B. Silva and G. A. R. Pereira participated in the coordination of the study, edited the data set and performed preliminary analyses. All authors read and approved the final manuscript.

\section{Acknowledgments}

This study received financial support from the Brazilian Council for Scientific and Technological Development (CNPq) and technical support from the International Atomic Energy Agency (IAEA) for providing the labeled urea used in the ${ }^{13} \mathrm{C}$-Urea Breath Tests. 


\section{References}

1. Bini EJ. Helicobacter pylori and iron deficiency anemia: guilty as charged? Am J Med 2001; 111:495-7.

2. DuBois S, Kearney DJ. Iron-deficiency anemia and Helicobacter pylori infection: a review of the evidence. Am J Gastroenterol 2005; 100:453-9.

3. World Health Organization/United Nations University/United Nations Children Fund. Iron deficiency anaemia: assessment, prevention, and control. A guide for programme managers. Geneva: World Health Organization; 2001.

4. Zubillaga M, Oliveri P, Panarello H, Buzurro M, Adami J, Goldman C, et al. Stable isotope techniques for the detection of Helicobacter pylori infection in clinical practice. 13C-Urea Breath Test in different experimental conditions. Acta Physiol Pharmacol Ther Latinoam 1999; 49:101-7.

5. Batista Filho M, Rissin A. A transição nutricional no Brasil: tendências regionais e temporais. Cad Saúde Pública 2003; 19 Suppl 1:S181-91.

6. Fabian C, Olinto MTA, Dias-da-Costa JS, Bairros F, Nácul LC. Prevalência de anemia fatores associados em mulheres adultas residentes em São Leopoldo, Rio Grande do Sul, Brasil. Cad Saúde Pública $2007 ; 23: 1199-205$.

7. Santos IS, Boccio J, Santos AS, Valle NC, Halal CS, Bachilli MC, et al. Prevalence of Helicobacter pylori infection and associated factors among adults in Southern Brazil: a population-based cross-sectional study. BMC Public Health 2005; 5:118.

8. Dias-da-Costa JS, Facchini LA. Utilização de serviços ambulatoriais em Pelotas: onde a população consulta e com que freqüência. Rev Saúde Pública 1997; 31:360-9.

9. Rothman KJ, Greenland S. Modern epidemiology. 2nd Ed. Philadelphia: Lippincott-Raven; 1998.

10. Capilheira MF, Santos IS. Fatores individuais associados à utilização de consultas médicas por adultos. Rev Saúde Pública 2006; 40:436-43.

11. Mendoza-Sassi R, Béria JU. Utilización de los servicios de salud: una revisión sistemática sobre los factores relacionados. Cad Saúde Pública 2001; 17:819-32.

12. Joint World Health Organization/Centers for Disease Control and Prevention Technical Consultation on the Assessment of Iron Status at the Population Level. Assessing the iron status of populations. Geneva: World Health Organization/Centers for Disease Control and Prevention; 2004.
13. Milman N, Rosenstock S, Andersen L, Jorgensen T, Bonnevie O. Serum ferritin, hemoglobin, and Helicobacter pylori infection: a seroepidemiologic survey comprising 2794 Danish adults. Gastroenterology 1998; 115:268-74.

14. Parkinson AJ, Gold BD, Bulkow L, Wainwright RB, Swaminathan B, Khanna B, et al. High prevalence of Helicobacter pylori in the Alaska native population and association with low serum ferritin levels in young adults. Clin Diagn Lab Immunol 2000; 7:885-8.

15. Baggett HC, Parkinson AJ, Muth PT, Gold BD, Gessner BD. Endemic iron deficiency associated with Helicobacter pylori among school-aged children in Alaska. Pediatrics 2006; 117:e396-404.

16. Cardenas VM, Mulla ZD, Ortiz M, Graham DY. Iron deficiency and Helicobacter pylori infection in the United States. Am J Epidemiol 2006; 163:127-34.

17. Choe YH, Kim SK, Son BK, Lee DH, Hong YC, Pai $\mathrm{SH}$. Randomized placebo-controlled trial of $\mathrm{He}$ licobacter pylori eradication for iron-deficiency anemia in preadolescent children and adolescents. Helicobacter 1999; 4:135-9.

18. Ciacci C, Sabbatini F, Cavallaro R, Castiglione F, Di Bella S, Iovino P, et al. Helicobacter pylori impairs iron absorption in infected individuals. Dig Liver Dis 2004; 36:455-60.

19. Valiyaveettil AN, Hamide A, Bobby Z, Krishnan R. Effect of anti-Helicobacter pylori therapy on outcome of iron-deficiency anemia: a randomized, controlled study. Indian J Gastroenterol 2005; 24:155-7.

20. Gessner BD, Baggett HC, Muth PT, Dunaway E, Gold BD, Feng Z, et al. A controlled, householdrandomized, open-label trial of the effect that treatment of Helicobacter pylori infection has on iron deficiency in children in rural Alaska. J Infect Dis 2006; 193:537-46.

Submitted on $09 /$ Oct/2008

Final version resubmitted on $05 / \mathrm{Aug} / 2009$ Approved on 30/Sep/2009 